\title{
AC 2008-1670: CIVIL AND ENVIRONMENTAL ENGINEERING EDUCATION (CEEE) TRANSFORMATIONAL CHANGE: TOOLS AND STRATEGIES FOR SUSTAINABILITY INTEGRATION AND ASSESSMENT IN ENGINEERING EDUCATION
}

qiong zhang, Michigan Technological University

Dr. Qiong Zhang is a Senior Research Engineer and Adjunct Assistant Professor of Civil \& Environmental Engineering at Michigan Technological University.

\section{Julie Zimmerman, Yale University}

Dr. Julie Zimmerman is an Assistant Professor jointly appointed to the Department of Chemical Engineering, Environmental Engineering Program and the School of Forestry and Environment.

James Mihelcic, Michigan Technological University

Dr. James R. Mihelcic is a Professor of Civil \& Environmental Engineering at Michigan Technological University.

Linda Vanasupa, California Polytechnic State University

Linda Vanasupa is a Professor and the Chair of Materials Engineering Department at California Polytechnic State University. 


\title{
Civil and Environmental Engineering Education (CEEE) Transformational Change: Tools and Strategies for Sustainability Integration and Assessment in Engineering Education
}

\begin{abstract}
This paper is based on a new project recently funded by the National Science Foundation which focuses on addressing some of the current barriers to integrating sustainability into engineering education - creating effective learning materials and proving the effectiveness of new teaching strategies - that enables engineering faculty to more easily incorporate sustainability approaches into curricula. The objectives of the project are to design, develop, implement, disseminate, and assess the success and effectiveness of the proposed transformational learning practices and peerto-peer networks. The paper begins with a brief overview of the entire project and then focuses on: 1) the components of a new textbook created for an Introduction to Environmental Engineering course and 2) identical Green Engineering courses to be offered at partner universities that build upon the introductory course.
\end{abstract}

The concept of incorporating and leveraging Fink's taxonomy of significant learning in the textbook and the course design is introduced and discussed. The paper also discusses how the textbook and the teaching/learning practices employed in the green engineering courses align with principles for good practice in undergraduate education and demonstrated successful teaching methods in engineering education.

\section{Introduction}

Sustainability has been receiving an increasing amount of attention by the global community in the past decade. Sustainability is often defined as "meeting the needs of the current generation without compromising the ability of future generations to meet their own needs" . This is often practically interpreted as mutually advancing the long-terms goals of economic growth, societal prosperity, and environmental protection. While there is an on-going debate on the major challenges to sustainability, most engaged in these discussions would suggest that issues such as population, water, the built environment, and energy ${ }^{2}$ are at the forefront.

The population discussion is particularly relevant given the fundamental goal of a high quality of life for all global citizens. This suggests that civil infrastructure systems (CIS) that provide basic needs such as water treatment and sanitation and shelter must be addressed. Water is critical to meeting human needs, preserving the natural environment, and advancing economic activities. The CEE community plays a vital role in managing water resources and, with improved knowledge and understanding of sustainability, can be engaged to design improved water supplies in a sustainable and locally appropriate manner in the developing world and provide intelligent water systems for the developed world to protect this invaluable global resource. The built environment is the result of human intervention in the natural physical world. While only $2-3 \%$ of North America's land area is built on, approximately $60 \%$ of the North American land area is now impacted by the built environment ${ }^{3}$. 
From this short discussion outlining several key challenges to sustainability, there are clear opportunities for Civil and Environmental Engineers to play a significant role in providing improved quality of life for the global population through the design of CIS. Imperative to the effectiveness and long-term success of improved CIS is considering sustainability and appropriateness for the intended end-user systematically and holistically for the entire lifecycle at the design stage. Through such training, Civil and Environmental Engineers can and will contribute significantly to improving the natural environment, the quality of life and social conditions, and economic development.

There has been an increasing articulation of the need for future engineers to have this type of training and demonstrated significant learning in terms of sustainability with one example being the American Society of Civil Engineering (ASCE) Code of Ethics which states that "The Code of Ethics of ASCE requires civil engineers to strive to comply with the principles of sustainable development in the performance of their professional duties...[including] global leadership in the promotion of responsible, economically sound, and environmentally sustainable solutions that enhance the quality of life, protect and efficiently use natural resources ". Since the United Nations Stockholm Conference on the Human Environment in 1972, there has been growing international interest in the role of higher education in fostering a sustainable future ${ }^{5}$. Agenda $21^{6}$ and a series of higher education for sustainable development declarations in the 1990s made this agenda explicit. The engineering community itself has also recognized this need through the NAE leadership ${ }^{7}$ and various professional societies ${ }^{8-10}$, through the NAE's Engineer 2020 report $^{11}$ and within ABET's new undergraduate education assessment criteria, Engineering Criteria 2000 (EC 2000) $^{12}$. In fact, ABET's EC 2000 establishes accreditation assessment criteria based upon their ability "to demonstrate that their students attain an ability to design...to meet desired needs within realistic constraints such as economic, environmental, social, political, ethical, health and safety, manufacturability, and sustainability...to understand the impact of engineering solutions in a global, economic, environmental, and societal context" ${ }^{\prime 2}$ making the need for the type of training and significant learning in undergraduate engineering experience proposed in this project explicit.

Deficiencies in engineering education have been exhaustively enumerated in recent years ${ }^{13}$.

Engineering schools and professors have been told by countless panels and blue-ribbon commissions and, ABET, that more must be taught about "real-world" engineering design and operations; more material in frontier areas of engineering such as sustainability should be covered; additional and improved instruction in both oral and written communication and teamwork skills should be offered; training in critical and creative thinking skills and problemsolving methods should be provided; and graduates who are conversant in engineering ethics and connections between technology and society should be produced $^{13}$. The ideas embedded within the significant learning taxonomy (Figure 1) are highly

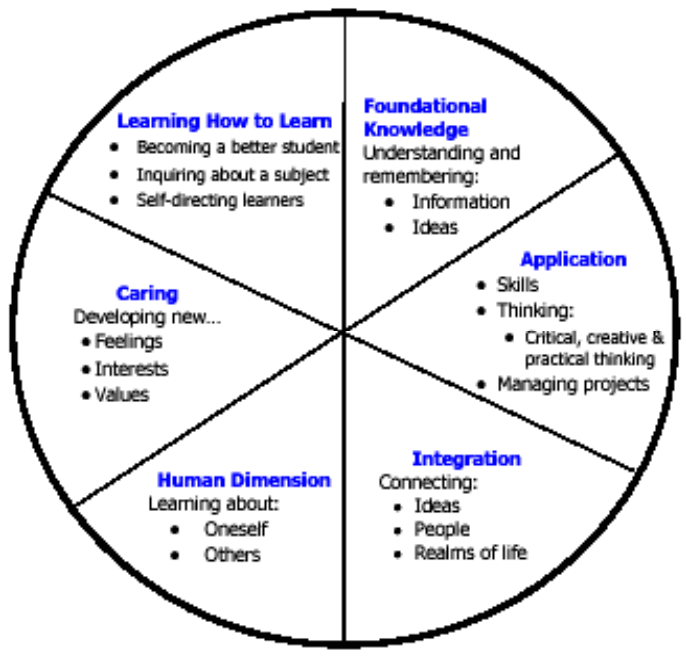

FIGURE 1: Fink's taxonomy of significant learning ${ }^{14}$ 
relevant to concepts and goals of sustainability by asking the learner to take foundational knowledge and apply it to critical, creative problem solving while integrating it with ideas of social systems, which can include economic markets. This includes creating a human dimension and empathy, engineers engaged in sustainable design of appropriate engineering systems where conditions and definition of success may change with location and culture requiring the CEE community to continually adapt their designs to new information and often times generate new, innovative solutions for a particular situation.

\section{Overview of the Project}

To integrate sustainability into engineering education, effective learning materials and teaching strategies have to be created that enables engineering faculty to more easily incorporate sustainability approaches into curricula. This paper is based on a new project recently funded by the National Science Foundation which focuses on addressing these issues. The goal of this project is to move the $\mathrm{CEE}$ community from the current status quo to an enhanced vision state, in which CEE faculty and students exhibit the ability to implement sustainability practices and demonstrate significant learning of sustainability concepts. The objectives of this project are to design, develop, implement, disseminate, and assess the success and effectiveness of the proposed leaning materials, transformational learning practices and peer-to-peer networks.

The key elements of this project include:

1. implementing and disseminating a textbook focused on the fundamentals of civil and environmental engineering with innovations in sustainability training, the best practices of undergraduate education, and awareness of the significant learning taxonomy;

2. developing and disseminating drop-in course modules based on the textbook that can be used by faculty in other disciplines other than CEE to introduce sustainability into their fundamentals discussions;

3. implementing identical "Green Engineering” courses at partner universities simultaneously;

4. implementing educational innovations in the form of student-to-student networks between partner universities for conducting team-based, inter-university campus sustainability projects and international design experience;

5. developing faculty expertise by disseminating learning materials and practices (the textbook, drop-in modules, green engineering courses, and team-based projects implemented at partner universities) through faculty workshops and related activities will be similar to those used in student courses, an example of faculty-to-faculty networks; and

6. evaluating and assessing these transformational learning practices and peer-to-peer networks for enabling implementation of sustainable practices, higher orders of significant learning in terms of sustainability, and increases in the factors shown to aid recruitment and retention of students in CEE, a STEM-related discipline.

The project started in October 2007, and several key elements described above are still in the planning stage, such as drop-in course modules. One example of a module is "Introduction to Sustainability." This module includes the definition of sustainability and the concept of mutually advancing economic, environmental, and social goals, evolution from pollution control to sustainability, and existing methods of sustainability assessment. Since the development of those elements has just been initiated, they will not be part of this paper. 
This paper focuses only on elements 1 and 3 - the components of a new textbook created for an Introduction to Environmental Engineering course and identical Green Engineering courses to be offered at partner universities that build upon the introductory course. The development of these learning materials and practices demonstrates how to incorporate and leverage Fink's taxonomy of significant learning in the textbook and the course design and how the textbook and the teaching/learning practices employed in the green engineering courses align with principles for good practice in undergraduate education and demonstrated successful teaching methods in engineering education.

\section{Innovations in Creating Learning Materials and Courses}

\section{Innovative Textbook}

The textbook to be implemented and disseminated in this project is titled Environmental Engineering: Fundamentals, Sustainability, Design ${ }^{15}$. The book will be published by John Wiley \& Sons (New York) and available for the academic year beginning in 2008. Table 1 provides a list of the 14 chapters. The components of this new textbook are created for an Introduction to Environmental Engineering course offered in many universities. The intended audience is undergraduate civil and environmental engineering (CEE) students. For example, at Michigan Tech, second-year environmental engineering students take this course and third-and fourth-year civil engineering students take it as a required terminal course. The potential audience is large. For example, Gibbons ${ }^{16}$ reported that in 2004-2005, the number of bachelor's degrees awarded in civil engineering was 8,247 and the number of bachelor's degrees awarded in environmental engineering (civil/environmental engineering) was 634.

TABLE 1: Table of Contents for Environmental Engineering: Fundamentals, Sustainability, Design $^{15}$.

\begin{tabular}{|l|l|}
\hline Chapter & Title \\
\hline 1 & Engineering \& Sustainable Development \\
\hline 2 & Environmental Measurements \\
\hline 3 & Chemistry \\
\hline 4 & Physical Processes \\
\hline 5 & Biology \\
\hline 6 & Environmental Risk \\
\hline 7 & Green Engineering \\
\hline 8 & Water Quality \\
\hline 9 & Water Supply, Distribution, and Wastewater Collection \\
\hline 10 & Water Treatment \\
\hline 11 & Wastewater Treatment \\
\hline 12 & Air Resources Engineering \\
\hline 13 & Solid Waste Management \\
\hline 14 & Built Environment \\
\hline
\end{tabular}

The new book builds upon a previous textbook (Fundamentals of Environmental Engineering ${ }^{17}$ ). That book had as it focus, scientific fundamentals applied to environmental problems (Chapters 
2-5 in the new book). The new book will still provide detailed coverage of environmental engineering fundamentals that are updated to incorporate sustainability issues, such as energy, water scarcity and conflict, population, climate change, equity, and materials use. There is also a chapter included on environmental risk (Chapter 6). More importantly, the book includes comprehensive development of basic design principles required of students and applied by practicing professionals (Chapters 8-13). In addition to this rigorous coverage of traditional environmental engineering subjects (e.g., water supply and treatment, wastewater treatment, solid waste management), the book presents "pro-active" alternatives to solving environmental problems by educating engineering students in principles of sustainability and green engineering (Chapters 1 and 7). These concepts are then integrated into every chapter, even when discussing issues of end-of-the-pipe treatment. For example, it provides emerging engineering solutions such as low impact storm water management (in Chapter 8), plant based wastewater treatment systems (Chapter 11), water reuse (Chapter 11), and has a complete chapter devoted to engineering a more sustainable built environment (Chapter 14).

Based on the Seven Principles for Good Practice in Undergraduate Education ${ }^{18}$ and demonstrated by successful teaching methods in engineering education ${ }^{13}$, the book includes active learning exercises such as team-based problems and role playing scenarios; learning objectives at the beginning of the chapter (and keywords at the end of a chapter) so users can determine if they focusing on and understanding the important points; multiple learning and teaching techniques such as visual aids, abstract discussions, and real-world case studies applied to a student's community; and sections on context and relevance for the material particularly relating the information in the book to the design of a sustainable future. Based on feedback from the students as well as faculty trained to use the book, the book's supporting material will be refined and optimized to enable significant learning and implementation of sustainability practices.

The book incorporates Fink's taxonomy of significant learning ${ }^{14}$ in its design. Unlike Bloom's taxonomy, which has common use in engineering education ${ }^{19}$, the Fink taxonomy takes an integrated approach to development, including dimensions of social and emotional development with the cognitive development, which enable the student to become more aware of their learning process, a critical component in ones' transition to a life-long learner. Table 2 shows how the book incorporates Fink's taxonomy.

TABLE 2: Textbook design with incorporation of Fink's taxonomy.

\begin{tabular}{|l|l|l|}
\hline Fink's taxonomy & Textbook design & How it relates \\
\hline Foundational & $\begin{array}{l}\text { - learning objectives at the beginning } \\
\text { of the chapter } \\
\text { - keywords at the end of a chapter }\end{array}$ & $\begin{array}{l}\text { help students understand and } \\
\text { remember key information and } \\
\text { ideas }\end{array}$ \\
\hline Application & $\begin{array}{l}\text { - fundamental knowledge in previous } \\
\text { chapters is then applied in later } \\
\text { chapters to creative approaches to } \\
\text { engineering problem solving }\end{array}$ & $\begin{array}{l}\text { help students apply knowledge } \\
\text { previously leaned to solve the } \\
\text { problems using creative } \\
\text { approaches, think critically to } \\
\text { present the solutions in the team } \\
\text { environment, and learn how to } \\
\text { manage the team projects }\end{array}$ \\
& $\begin{array}{l}\text { team-based problems and role playing } \\
\text { scenarios }\end{array}$ & real-world case studies \\
\hline Integration & fundamental knowledge in previous & \\
\hline
\end{tabular}




\begin{tabular}{|c|c|c|}
\hline & $\begin{array}{l}\text { chapters is then applied in later } \\
\text { chapters } \\
\text { - material relating the information in } \\
\text { the book to the design of a } \\
\text { sustainable future } \\
\text { - team-based problems and role playing } \\
\text { scenarios } \\
\text { - real-world case studies } \\
\end{array}$ & $\begin{array}{l}\text { within the course, work with } \\
\text { team members to recognize the } \\
\text { connection with other } \\
\text { disciplines, understand the } \\
\text { interactions among the material } \\
\text { in the course and their real life }\end{array}$ \\
\hline $\begin{array}{l}\text { Human } \\
\text { Dimension }\end{array}$ & $\begin{array}{l}\text { - } \text { the concept of human systems and } \\
\text { social connectedness to engineering } \\
\text { problem solving } \\
\text { - discussion on environmental risk } \\
\text { includes issues of environmental } \\
\text { justice } \\
\text { - team-based problems and role playing } \\
\text { scenarios }\end{array}$ & $\begin{array}{l}\text { help students learn about human } \\
\text { systems and their interaction } \\
\text { with environment, and } \\
\text { understanding team members } \\
\text { and interacting with them }\end{array}$ \\
\hline Caring & $\begin{array}{l}\text { - the concept of sustainability where } \\
\text { economic, societal, and } \\
\text { environmental systems are integrated }\end{array}$ & $\begin{array}{l}\text { Help students adopt the systems } \\
\text { perspective of engineering } \\
\text { solutions and develop feelings } \\
\text { for the environment and society }\end{array}$ \\
\hline $\begin{array}{l}\text { Learning how to } \\
\text { learn }\end{array}$ & $\begin{array}{l}\text { - learning objectives at the beginning } \\
\text { of the chapter }\end{array}$ & $\begin{array}{l}\text { Help students set a learning } \\
\text { agenda of what they need to } \\
\text { learn and make a learning plan }\end{array}$ \\
\hline
\end{tabular}

The theme of sustainability aligns very well with the taxonomy of significant learning. It allows the student to be more creative in their problem solving because sustainable solutions are usually not the traditional solution used historically by engineering practitioners. It has also provided a strong social connectedness to engineering problem solving where the concept of human systems and social justice (i.e., equity) now become integrated into the engineering solution. For example, two learning objectives of the chapter on Environmental Risk (Chapter 6) are that students will be able to 1) describe the different types of hazard and their potential adverse impacts on human health and the environment and 2) define the terms environmental justice and susceptible populations in relation to risk assessment and the role engineers can play. Chapter 6 also specifically informs students that green chemistry and green engineering are methods to lower the hazard towards zero, and thus the risk. There are also sections on how environmental justice is related to human rights, and how this is incorporated into engineering practice.

\section{Identical Green Engineering Courses}

The interdisciplinary engineering course "Green Engineering and Sustainability" will be implemented at both Michigan Tech and Yale University by different instructors as identical courses. This course will be offered as a selective course for both Junior and Senior students from all engineering disciplines and serve as a follow on course for those who have used the new textbook Environmental Engineering: Fundamentals \& Design as described above in their introductory course. 
The Green Engineering course will provide a foundation for green engineering design and sustainability. The class will review Evolution of Engineering Design, challenges to sustainability in both the developed and developing world and the role of engineering design in achieving global sustainability. The current approach to engineering design in terms of process design, material selection and energy consumption will be discussed in the context of infrastructure systems. The principles of green engineering ${ }^{20}$ will be introduced and the topics on the application of these principles that will be addressed include risk, pollution prevention and source reduction, material and energy flows and efficiencies, system analysis, life cycle assessment/costing/management, and innovative designs (e.g., appropriate technologies, biomimicry).

While the course will have traditional components of lectures led by the instructor in each campus and seminars with the same guest speakers delivered via distance, it has several unique features: 1) non-traditional syllabus where students and faculty will collectively make decisions on course structure and rules. Through this exercise, students will understand that they are part of the course and learn how to measure their performance in the course. 2) team-based, openended problems where students will actively learn the course content and apply it. For example, students can take apart of common household products to identify and sort material types, perform a life cycle analysis, and analyze the design for potential improvements in terms of sustainability. Students can use inexpensive kits available on the market to convert solar energy into electricity, with subsequent use of the electricity to generate hydrogen and use it in a fuel cell. Students could calculate efficiencies at the various conversion steps and evaluate the life cycle impact of various energy options and make recommendations on improvements. 3) student-student peer networks between Michigan Tech and Yale University for completing a semester-long campus sustainability project advised by the instructor on each campus. The campus sustainability project is based on the idea that campuses are living laboratories and provide numerous opportunities for students to affect real and valuable change as demonstrated by the growing number of projects ${ }^{21-22}$. A team of students on each campus will select a project to implement on their home campus. A collaborative website will be created to provide a repository of information, presentations, and case-studies on various campus sustainability projects. This will create a valuable student-student peer resource that each team can draw on for common information that can contribute to the success of the project such as data generated on environmental and economic benefits; successful strategies for information dissemination to students, faculty, and staff; opportunities to engage the university administration; and enhancing the long-term likelihood of success of the project. The process of identifying a challenge to sustainability on their campus, designing a solution, and developing (and ideally) implementing a plan to realize their goal will provide the students with many of the hands-on experiences necessary to achieve significant learning of sustainability and deepen their understanding of foundational engineering knowledge as they put it into practice in a real-world situation.

As mentioned above, a collaborative website will be created for information exchange and active interactions between the two universities. In addition, to ensure the courses are successfully implemented at both universities, the instructor on each campus will work closely on the course materials, the pace of lectures, the schedule of guest speakers, the progress of the campus sustainability projects and the course assessment through teleconferences, emails, online discussion and annual face-to-face meetings. 
The differences between conventional curricula and some of the core proposed course activities are summarized in Figure 2 below. Table 3 demonstrates how learning activities in the Green Engineering course are designed for active learning which is critical for achieving significant learning goals.
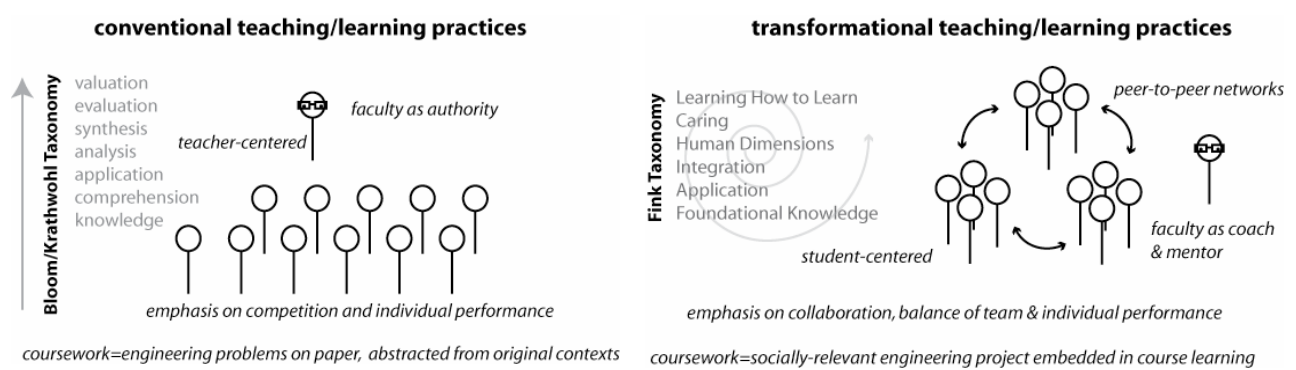

FIGURE 2: Differences between (A) conventional curricula and (B) some of the core proposed course activities with their corresponding appropriate assessment taxonomies. In (B), the spiral represents Fink's view that these levels are interactive, where significant learning results require all of these different kinds of learning.

TABLE 3: Learning activities in the Green Engineering courses for holistic active learning

\begin{tabular}{|c|c|c|}
\hline $\begin{array}{l}\text { Getting } \\
\text { information \& } \\
\text { ideas }\end{array}$ & Experience & Reflective Dialogue \\
\hline $\begin{array}{ll}\text { - } & \text { lectures } \\
\text { - } & \text { textbooks } \\
\text { - } & \text { seminars from } \\
& \text { guest speakers } \\
\text { - } & \text { collaborative } \\
& \text { websites }\end{array}$ & $\begin{array}{l}\text { - take apart of common household } \\
\text { products to identify and sort material } \\
\text { types } \\
\text { - } \text { convert energy } \\
\text { - } \text { use softwares (e.g., SimaPro, EIO- } \\
\text { LCA) to perform life cycle analysis } \\
\text { - case-studies } \\
\text { - role play } \\
\text { - campus sustainability projects }\end{array}$ & $\begin{array}{l}\text { - } \text { students and faculty } \\
\text { collectively make decisions on } \\
\text { course structure and rules } \\
\text { - } \text { end of class discussions on the } \\
\text { course materials and learning } \\
\text { problems } \\
\text { - } 1 \text {-minute tests } \\
\text { - perceived value questionnaires } \\
\text { - } \text { student-student peer networks }\end{array}$ \\
\hline
\end{tabular}

\section{Assessment and evaluation design}

Through the assessment process, we intend to answer fundamental questions regarding the transformational teaching/learning practices utilized in the peer-to-peer networks: 1) Do they enable the implementation of sustainable practices? 2) Do they result in higher orders of significant learning? To answer these questions, we will utilize several instruments that have been developed and validated. We also will develop four assessment tools to enable direct measurements of students' performance along their knowledge and application of sustainable design, the value of peer-to-peer networks for implementing sustainable practices. This assessment approach is designed to measure students' progress within several dimensions of Fink's taxonomy, including Learning how to learn (self-directed learning), Foundational 
knowledge (understanding of the connections between engineering solutions and global issues), Application (ability to design for sustainability), Caring (motivation, interest), and Human dimension (moral reasoning). For the assessment, we are proposing to demonstrate that students involved in the project are more developed along several measures (cognitive, affective, and social) compared to those who do not participate in this program. Table 4 summarizes the hypotheses and our assessment plan toward each.

TABLE 4: Summary of Assessment Strategy. Instruments that will be developed during the proposed research are indicated by $\lambda$.

\begin{tabular}{|c|c|}
\hline \multicolumn{2}{|c|}{ Transformational learning practices and peer-to-peer networks: } \\
\hline \multicolumn{2}{|c|}{ Hypothesis 1: Enable Implementation of sustainable practices } \\
\hline evidenced by & assessed through \\
\hline $\begin{array}{l}\text { 1. students' advanced } \\
\text { understanding of connections } \\
\text { between engineering solutions } \\
\text { and global issues }\end{array}$ & $\begin{array}{l}\text { Comparison of performance of partner universities } \\
\text { students to control cohort performance } \\
\text { direct measure of understanding }\end{array}$ \\
\hline $\begin{array}{l}\text { 2. students utilizing peer-to-peer } \\
\text { networks to implement effective } \\
\text { sustainability projects }\end{array}$ & $\begin{array}{l}\text { Student questionnaire } \\
\text { direct measure of students' perceived value of the } \$ \\
\text { peer-to-peer network }\end{array}$ \\
\hline $\begin{array}{l}\text { 3. faculty utilizing the peer-to-peer } \\
\text { network to integrate } \\
\text { sustainability concepts into their } \\
\text { curricula }\end{array}$ & $\begin{array}{l}\text { Faculty questionnaire } \\
\text { Direct measure of faculty's perceived value of peer- } \\
\text { to-peer network }\end{array}$ \\
\hline Hypothesis 2: Result in higher orc & of significant learning \\
\hline evidenced by & assessed through \\
\hline $\begin{array}{l}\text { 1. students' application of } \\
\text { sustainability design principles } \\
\text { ("application" in Fink's } \\
\text { significant learning taxonomy }{ }^{14} \text { ) }\end{array}$ & $\begin{array}{l}\text { Performance of partner universities students in } \\
\text { sustainability projects } \\
\text { direct measure of ability to design } \\
\text { Score on modified Safoutin et al.'s design } \\
\text { questionnaire } \\
\text { direct measure of students' perception of their design } \\
\text { abilities }\end{array}$ \\
\hline $\begin{array}{l}\text { 2. students' higher scores on } \\
\text { moral/ethical reasoning } \\
\text { ("Human Dimension" in Fink's } \\
\text { significant learning taxonomy }{ }^{14} \text { ) }\end{array}$ & $\begin{array}{l}\text { Comparison of participating student scores on } \\
\text { Defining Issues Test (DIT-2) } \\
\text { scores } \\
\text { direct measure of moral and ethical reasoning }\end{array}$ \\
\hline $\begin{array}{l}\text { 3. students' advanced abilities in } \\
\text { self-directed learning and } \\
\text { valuation of peers in learning } \\
\text { ("Learning How to Learn" in } \\
\text { Fink's significant learning } \\
\text { taxonomy }{ }^{14} \text { ) }\end{array}$ & $\begin{array}{l}\text { Comparison of participating student scores on } \\
\text { Motivated Strategies for Learning Questionnaire } \\
(M S L Q)^{25} \text { to non-participant scores } \\
\text { Correlation analysis of scores on } M S L Q \text { and } \\
\text { performance in item H2-1 (students' application of } \\
\text { sustainability design principles) } \\
\text { direct measure of students' ability to monitor their } \\
\text { own learning }\end{array}$ \\
\hline
\end{tabular}




\section{Discussion}

As discussed before, to achieve significant learning in term of sustainability, the textbook and transformational learning practices and peer-to-peer network elements in identical Green Engineering courses presented are carefully designed based on the Seven Principles for Good Practice in Undergraduate Education and closely align with documented successful demonstrated teaching methods as shown in Table 5. For example, in the green engineering course, the successful project-based learning and service-learning methods are adopted in campus sustainability projects, in which students work in teams to solve open-ended problems and serve their campus community.

TABLE 5: Alignment of textbook and Green Engineering course elements with Seven Principles for Good Practice in Undergraduate Education ${ }^{18}$ and Demonstrated Successful Teaching Methods in Engineering Education ${ }^{13}$.

\begin{tabular}{|c|c|c|}
\hline $\begin{array}{l}\text { Seven } \\
\text { Principles for } \\
\text { Good Practice } \\
\text { in } \\
\text { Undergraduate } \\
\text { Education }\end{array}$ & $\begin{array}{l}\text { Demonstrated } \\
\text { Successful Teaching } \\
\text { Methods in } \\
\text { Engineering } \\
\text { Education }\end{array}$ & $\begin{array}{l}\text { Textbook and Green Engineering course } \\
\text { elements }\end{array}$ \\
\hline $\begin{array}{l}\text { Encourage } \\
\text { contact between } \\
\text { students and } \\
\text { faculty }\end{array}$ & $\begin{array}{l}\text { Convey a sense of } \\
\text { concern about the } \\
\text { students' learning }\end{array}$ & $\begin{array}{l}\text { - the textbook's supporting material will be } \\
\text { refined and optimized based on feedback } \\
\text { from students and faculty } \\
\text { - } \text { students and faculty collectively make } \\
\text { decisions on course structure and rules } \\
\text { - end of class discussions among faculty and } \\
\text { students }\end{array}$ \\
\hline $\begin{array}{l}\text { Develop } \\
\text { reciprocity and } \\
\text { cooperation } \\
\text { among students }\end{array}$ & $\begin{array}{l}\text { Use cooperative } \\
\text { learning }\end{array}$ & $\begin{array}{l}\text { - team-based projects } \\
\text { - Inter- and intra-university peer-to-peer } \\
\text { student teams for campus sustainability } \\
\text { projects }\end{array}$ \\
\hline $\begin{array}{l}\text { Uses active } \\
\text { learning } \\
\text { techniques }\end{array}$ & $\begin{array}{l}\text { Promote active } \\
\text { learning in the } \\
\text { classroom }\end{array}$ & $\begin{array}{l}\text { team-based problems and role playing } \\
\text { scenarios in the textbook } \\
\text { - learning practices in Green Engineering } \\
\text { courses as shown in Table } 3\end{array}$ \\
\hline $\begin{array}{l}\text { Gives prompt } \\
\text { feedback }\end{array}$ & & $\begin{array}{l}\text { - continuous monitoring and assessment } \\
\text { during courses and projects with 1-minute } \\
\text { tests, perceived value questionnaires, and } \\
\text { targeted measurement of significant } \\
\text { learning }\end{array}$ \\
\hline $\begin{array}{l}\text { Emphasizes } \\
\text { time on task }\end{array}$ & & $\begin{array}{l}\text { - courses simultaneously offered on two } \\
\text { campuses will require close coordination } \\
\text { and timing in terms of learning experiences }\end{array}$ \\
\hline $\begin{array}{l}\text { Communicates } \\
\text { high } \\
\text { expectations }\end{array}$ & $\begin{array}{l}\text { Formulate and } \\
\text { publish clear } \\
\text { instructional }\end{array}$ & $\begin{array}{l}\text { - learning objectives at the beginning of each } \\
\text { chapter in the textbook }\end{array}$ \\
\hline
\end{tabular}




\begin{tabular}{|l|l|l|}
\hline & objectives & $\bullet \begin{array}{l}\text { explicit goals and objectives are developed } \\
\text { for the course }\end{array}$ \\
\hline $\begin{array}{l}\text { Respects } \\
\text { diverse talents } \\
\text { and ways of } \\
\text { learning }\end{array}$ & $\bullet \begin{array}{l}\text { curricula materials will be offered through } \\
\text { numerous mechanisms, such as lectures, } \\
\text { readings, group projects, team } \\
\text { collaboration, collaborative website, and } \\
\text { hands-on activities }\end{array}$ \\
\hline & $\begin{array}{l}\text { Establish relevance of } \\
\text { course materials and } \\
\text { teach inductively }\end{array}$ & $\bullet \begin{array}{l}\text { real-world case studies } \\
\text { campus sustainability projects }\end{array}$ \\
\hline
\end{tabular}

Through the innovative textbook and transformational learning practices and peer-to-peer network elements in identical Green Engineering courses, students will not only build knowledge base on sustainability but also apply this knowledge to solve the real-world problems in their campus sustainability projects. Designing an innovative solution to campus sustainability challenges through inter- and intra-university peer-to-peer network diversified in terms of disciplines and knowledge provides the students with learning environment of external knowledge and opportunities to analyze, synthesize, evaluate and make decisions cooperatively, which stimulate critical thinking, creative thinking and practical thinking. Once the results from the carefully designed assessment are available, the effectiveness of these learning materials and practices advancing engineering education in sustainability can be evaluated in terms of higher orders of significant learning.

\section{Conclusions}

The concepts and goals of sustainability are highly relevant to ideas embedded within the significant learning taxonomy. This is the field which has potential to advance engineering education. The learning materials and practices designed for significant learning clearly align well with principles for good practice in undergraduate education and demonstrated successful teaching methods in engineering education.

\section{Bibliography}

1. The World Commission on Environment and Development, U.N., Our Common Future, New York: Oxford University Press, 1987.

2. Anastas, P., "Meeting the Challenges to Sustainability through Green Chemistry," Journal of Green Chemistry, 5(2): 29-G34, 2003.

3. United Nations Environment Programme (UNEP), Global Environmental Outlook 3. London: Earthscan Publications, Ltd., 2002.

4. American Society of Civil Engineering (ASCE), The role of the civil engineer in sustainable development. 2001.

5. Calder, W. and R.M. Clugston, "Progress Toward Sustainability in Higher Education," Environmental Law Reporter, 33(1): 1003-23, 2003. 
6. United Nations Environment Programme (UNEP), Agenda 21. 1992.

7. Wulf, W.A. and G.M.C. Fisher, "A Makeover for Engineering Education," Issues in Science and Technology, 18(3):35-39, 2002.

8. American Institute of Chemical Engineers (AIChE). Institute for Sustainability, Mission Statement, www.aiche.org/IFS/About/Mission/aspx

9. American Society of Civil Engineering (ASCE). Code of Ethics, www.asce.org/inside/codeofethics.cfm

10. American Society of Mechanical Engineers (ASME). A Declaration by the U.S. Engineering Community to the World Summit on Sustainable Development, ASME position statement, www.asme.org/gric/ps/2002/02-30.html

11. National Academy of Engineering (NAE), The Engineer of 2020: Visions of Engineering in the New Century. The National Academies Press: Washington, DC., 2004.

12. ABET. Criteria for Accrediting Engineering Program, Engineering Accreditation Commission, Nov. 2002.

13. Felder, R.M., D.R. Woods, J.E. Stice, A. Rugarcia, "The Future of Engineering Education. II. Teaching Methods that Work," Chemical Engineering Education, 34(1): 26-39, 2000.

14. Fink, L.D., Creating Significant Learning Experiences: An Integrated Approach to Designing College Courses, 1st ed. New York: Jossey-Bass, 2003.

15. Mihelcic, J.R. and J.B. Zimmerman (with M.T. Auer, D.W. Hand, R.E. Honrath, A.S. Mayer, J.A. Perlinger, N.R. Urban, Q. Zhang, K.G. Paterson, M.R. Penn, B.E. Whitman, M.W. Milke), Environmental Engineering: Fundamentals, Sustainability, Design, John Wiley \& Sons, 700 pages, publication in 2008.

16. Gibbons, M.T., The Year in Numbers. American Society for Engineering Education, 2006.

17. Mihelcic, J.R., Fundamentals of Environmental Engineering, John Wiley \& Sons, New York, 1999.

18. Chickering, A. and Z. Gamson, "Seven principles for good practice in undergraduate education," $A A H E$ Bulletin, 39(7):3-7, 1987.

19. Bloom, B.S., M.D. Englehart, E.J. Furst, W.H. Hill, and D.R. Krathwohl, Taxonomy of Educational Objectives: Handbook 1: Cognitive Domain. New York: Longmann, 1956.

20. Anastas, P.T. and J.B. Zimmerman, "Design through the Twelve Principles of Green Engineering," Environmental Science and Technology, 37(5):94A-101A, 2003.

21. Zimmerman, J.B., "EPA's P3 - People, Prosperity, and the Planet - Award," Sustainability: Science, Practice and Policy, 1(2):32-33, 2005.

22. Steinemann, A., "Implementing Sustainable Development through Problem-Based Learning: Pedagogy and Practice," Journal of Professional Issues in Engineering Education and Practice, 129(4):216-224, 2003.

23. Safoutin, M.J., C.J. Atman, R. Adams, T. Rutar, J.C. Kramlich, and J. L. Ridley, “A Design Attribute Framework for Course Planning and Learning Assessment," IEEE Transactions on Education, 43: 188-199, 2000.

24. Rest, J., D. Narvaez, M. Bebeau, and S. Thoma, "DIT-2: Devising and testing a new instrument of moral judgment," Journal of Educational Psychology, 91: 644-659, 1999. 
25. Pintrich, P.R., D.A.F. Smith, T. Garcia, and W.J. McKeachie, The Motivated Strategies for Learning Questionnaire (MSLQ), National Center for Research to Improve Postsecondary Teaching and Learning, University of Michigan, Ann Arbor 1987. 